Jurnal Teknologi, 37(B) Dis. 2002: 27-42

(C) Universiti Teknologi Malaysia

\title{
PERANAN FAKTOR STRUKTUR DALAM MODEL NILAI TANAH: KAJIAN KES BANDAR SURABAYA, INDONESIA
}

\author{
HENING WIDI OETOMO ${ }^{1} \&$ RUSLAN RAINIS ${ }^{2}$
}

\begin{abstract}
Abstrak. Model nilai tanah merupakan model untuk menaksir nilai tanah berdasarkan faktorfaktor yang dikenal pasti dapat mempengaruhi nilai tanah. Secara umum ada empat (4) kumpulan faktor yang mempengaruhi nilai tanah iaitu struktur, kejiranan, lokasi dan masa. Sebahagian besar daripada faktor ini memerlukan data ruangan yang dahulunya sukar dijana kerana kekurangan alatan yang sesuai. Perkembangan dalam sistem maklumat geografi (GIS) membolehkan berbagai-bagai jenis analisis ruangan yang diperlukan seperti pengkelasan semula, penindanan, pengukuran jarak dan kehampiran, kejiranan, rangkaian dan permukaan dapat dilakukan dengan lebih mudah. Kajian ini cuba membentuk satu model nilai tanah dengan memfokuskan kepada faktor struktur. Sebanyak empat pemboleh ubah struktur lot tanah diambil kira iaitu keluasan, lebar hadapan, indeks landskap (bentuk lot) dan arah orientasi. Kaedah statistik yang digunakan adalah analisis regresi terhadap sampel 148 transaksi lot tanah. Daripada analisis hanya dua pemboleh ubah iaitu luas dan bentuk lot signifikan pada tahap 0.05 dan berjaya menerangkan sebanyak $74 \%$ daripada variasi nilai tanah.
\end{abstract}

Kata kunci: nilai tanah, GIS, faktor struktur

\begin{abstract}
A model of land value is a model to estimate land value based on factors identified to influence land value. Generally, there are four groups of factors that influence land value i.e. structural, neighborhood, location and time. Most of these factors need spatial data that were difficult to generate in the past due to the lack of appropriate tools. The recent development in Geographical Information System (GIS) enables the various spatial analysis such as reclassification, overlay, distance measurement and proximity, neighborhood, network and surface analysis to be a carried out with ease. This study attempts to develop a land value model with a particular focus on structural factors. Four structural factors were considered in the model namely size, width of frontage, landscape index (shape of lot) and orientation. The model was developed using multiple regression analysis based on a sample of 148 lots of land transaction. From the analysis, only two variables i.e. size and landscape index were statistically significant at 0.05 level and successfully explained $74 \%$ of the variation in land value.
\end{abstract}

Key words: land value, GIS, structural factor

\subsection{PENGENALAN}

Beberapa institusi mempunyai kepentingan di atas penaksiran nilai tanah. Perbankan berkepentingan untuk menentukan nilai kredit, kerajaan berkepentingan untuk cukai tanah dan pelabur berkepentingan untuk transaksi jual beli tanah. Masing-masing

1 Unit GeoInformatik, Bahagian Geografi, Pusat Pengajian Ilmu Kemanusiaan, Universiti Sains Malaysia, 11800 Pulau Pinang. widi2010@hotmail.com

2 Unit GeoInformatik, Bahagian Geografi, Pusat Pengajian Ilmu Kemanusiaan, Universiti Sains Malaysia, 11800 Pulau Pinang.rruslan@usm.my 
institusi mempunyai ukuran menurut kepentingannya. Perbezaan ukuran mengakibatkan perbezaan taksiran nilai tanah. Oleh yang demikian ada keperluan untuk mewujudkan satu kaedah atau pendekatan yang universal yang mencerminkan pengaruh ciri-ciri tanah yang dinilai. Satu cara ke arah mencapai objektif ini adalah dengan membentuk model nilai tanah yang mengambil kira peranan berbagai-bagai atribut tanah terhadap nilainya. Secara umum, nilai tanah dipengaruhi oleh faktorfaktor struktur, faktor kejiranan dan lokasi. Sebahagian daripada faktor ini berkaitan rapat dengan ruang. Faktor ruangan merupakan satu alternatif ukuran yang boleh digunakan untuk menyatukan kepentingan sehingga menghasilkan satu nilai taksiran nilai tanah yang sama. Di masa lampau sumbangan faktor ruangan ini sukar diambil kira kerana kurangnya alat yang sesuai digunakan bagi menjana data ruangan. Namun begitu dengan perkembangan pesat dalam teknologi maklumat yang berkaitan dengan ruangan (seperti Sistem Maklumat Geografi - GIS) membenarkan pengkaji mengambil kira faktor-faktor ruangan dalam mengira nilai tanah.

Penggunaan teknologi dalam menyokong analisis ruangan dalam menentukan nilai tanah adalah penting. Wyatt (1996) berpendapat penggunaan teknologi dalam penentuan nilai tanah akan meningkatkan lagi mutu dan kualiti kerja. Beliau mendapati Sistem Maklumat Geografi (GIS) berkeupayaan untuk melakukan analisis terhadap data spatial bagi melihat pengaruh faktor kebolehsampaian terhadap nilai tanah. Peta nilai yang dihasilkan oleh GIS boleh digunakan untuk pelbagai tujuan seperti perancangan guna tanah yang optimum, pencukaian, pengurusan tanah, mengenal pasti kawasan yang mempunyai keupayaan pembangunan dan pelaburan di masa depan dan juga yang berkaitan dengan pengurusan dan penilaian tanah. Castle (1992) telah membuat kajian dan mengemukakan 462 peluang penggunaan GIS dalam bidang penilaian tanah. Perkara ini digambarkan dalam bentuk matriks tiga dimensi. Beliau percaya peluang-peluang penggunaan GIS masih boleh diperluas dan dipertingkatkan lagi dengan penggunaan pakej-pakej lain seperti Artificial Intel ligence/Expert System.

GIS kini digunakan dengan meluas di pelbagai sektor dan menjadi alat umum kepada berbagai-bagai profesion, contohnya ahli geografi, ahli perancang, ahli biologi, pengusaha infrastruktur asas (seperti jalan raya, telefon dan elektrik) dan ejen hartanah (Ruslan Rainis \& Noresah, 1998).

Penerapan GIS dalam sektor penilaian tanah di Indonesia masih lagi pada peringkat awal. Jabatan cukai harta menggunakan GIS dalam pembuatan data cukai harta bermula pada tahun 1996, dengan tugas utamanya ialah menyediakan peta berkomputer (Dirjen Cukai, 1998). Analisis ruangan yang merupakan kelebihan utama dalam GIS belum lagi digunakan sepenuhnya.

Artikel ini bertujuan untuk mendemonstrasikan aplikasi sistem maklumat geografi dalam membentuk model nilai tanah di Indonesia dengan penekanan kepada aspek faktor-faktor struktur. Keupayaan utama GIS digunakan dalam menjana data yang diperlukan untuk membentuk model nilai tanah di kawasan kajian. 


\subsection{KAJIAN MODEL NILAI TANAH TERDAHULU}

Beberapa model nilai hartanah telah dibentuk dan berbagai-bagai pemboleh ubah telah diambil kira oleh peneliti-peneliti terdahulu. Kajian mengenai model nilai tanah secara relatif adalah sedikit jika dibandingkan dengan model nilai hartanah atau nilai sewa hartanah. Jadual 1 menunjukkan empat model nilai tanah menggunakan model Hedonic. Model Hedonic adalah salah satu model yang banyak digunakan untuk pemodelan nilai hartanah, sewa hartanah mahupun nilai tanah. Model Hedonic secara amnya mengenal pasti secara tegas perlakuan yang kompleks dan heterogen pada produk rumah dan tanah.

Jadual 1 Model nilai tanah oleh 4 pengkaji terdahulu

\begin{tabular}{|c|c|c|}
\hline Pengkaji & Model Nilai Tanah & Pemboleh Ubah \\
\hline $\begin{array}{l}\text { Dowall \& } \\
\text { Leaf (1991) }\end{array}$ & $\mathrm{AT}=\mathrm{f}(\mathrm{IS}, \mathrm{J}, \mathrm{CH}, \mathrm{KC})$ & $\begin{array}{l}\text { 1. Anggaran harga tanah (AT) } \\
\text { 2. Infrastruktur (IS) } \\
\text { 3. Jenis pemilikan (JP) } \\
\text { 4. Cukai harta }(\mathrm{CH}) \\
\text { 5. Kecerunan }(\mathrm{KC})\end{array}$ \\
\hline Nelson (1993) & $\mathrm{HT}=\mathrm{f}(\mathrm{TP}, \mathrm{KB}, \mathrm{KC}, \mathrm{LS}, \mathrm{KT}, J \mathrm{~B}, \mathrm{~T}, \mathrm{JS})$ & $\begin{array}{l}\text { 1. Harga Tanah (HT) } \\
\text { 2. Tempoh penjualan (TP) } \\
\text { 3. Peratus kemungkinan banjir (KB) } \\
\text { 4. Kecerunan (KC) } \\
\text { 5. Luas (LS) } \\
\text { 6. Kualiti tanah (KT) } \\
\text { 7. Jarak ke pusat bandar (JB) } \\
\text { 8. Jarak ke tepi bandar (JT) } \\
\text { 9. Jarak ke sempadan bandar (JS) }\end{array}$ \\
\hline $\begin{array}{l}\text { Brondino \& } \\
\text { Silva (1998) }\end{array}$ & $\mathrm{HT}=\mathrm{f}(\mathrm{LS}, \mathrm{LB}, \mathrm{JB}, \mathrm{KJ}, \mathrm{BA}, \mathrm{SA}, \mathrm{BE})$ & $\begin{array}{l}\text { 1. Harga tanah (HT) } \\
\text { 2. Luas (LS) } \\
\text { 3. Lebar (LB) } \\
\text { 4. Jarak ke CBD (JB) } \\
\text { 5. Kualiti jalan (KJ) } \\
\text { 6. Bekalan air (BA) } \\
\text { 7. Saliran air (SA) } \\
\text { 8. Bekalan elektrik (BE) }\end{array}$ \\
\hline $\begin{array}{l}\text { Sun Sheng Han } \\
\& \text { Basuki (2001) }\end{array}$ & $\mathrm{NT}=\mathrm{f}(\mathrm{DCBD}, \mathrm{DHW}, \mathrm{DC}, \mathrm{ZN}, \mathrm{FR})$ & $\begin{array}{l}\text { 1. Nilai tanah (NT) } \\
\text { 2. Jarak ke CBD (DCBD) } \\
\text { 3. Jarak ke lebuhraya (DHW) } \\
\text { 4. Jarak ke pusat perniagaan (DC) } \\
\text { 5. Zoning (ZN) } \\
\text { 6. Risiko banjir (FR) }\end{array}$ \\
\hline
\end{tabular}


Model Hedonic secara amnya dapat dinyatakan dalam fungsi persamaan berikut:

$$
P=f\left(S_{1} \ldots S_{i}, N_{1} \ldots N_{j}, L_{1} \ldots L_{k}\right)
$$

di mana

$$
\begin{aligned}
& P=\text { Harga Tanah } \\
& S=\text { Faktor Struktur } \\
& N=\text { Faktor Kejiranan } \\
& L=\text { Faktor Lokasi }
\end{aligned}
$$

Perlakuan struktur adalah berkenaan dengan situasi fizikal lot tanah itu sendiri seperti kecerunan, kontur, arah, luas serta peruntukannya. Perlakuan kejiranan berkaitan dengan situasi sosial dan kemudahan am, seperti kualiti sekolah, jalan, air dan elektrik. Sedangkan perlakuan lokasi lebih merujuk kepada aksesibiliti kepada kemudahan ekonomi seperti jarak ke pusat bandar, kompleks membeli belah dan kemudahan ekonomi lainnya.

Model Hedonic dapat menjelaskan sumbangan tertentu setiap atribut sesuatu hartanah terhadap nilai hartanah tersebut dengan menggunakan analisis regresi berganda (Dubin, 1988). Keempat pengkaji di atas menggunakan kaedah yang sama iaitu analisis regresi berganda. Model yang dibangunkan oleh Dowall \& Leaf (1991) secara keseluruhan telah dapat menerangkan variasi nilai tanah $\left(R^{2}\right)$ sebesar $69.2 \%$, Nelson (1993) sebesar 81.1\%, Brondino \& Silva (1998) sebesar 82.5\% dan Sun Sheng Han \& Basuki (2001) sebesar 56\%. Ini menunjukkan model Hedonic mampu menerangkan variasi nilai tanah melebihi 50\%.

\subsection{MODEL CADANGAN}

Model yang dicadangkan adalah berasaskan kepada model Hedonic. Daripada tiga faktor utama yang terdapat dalam model Hedonic, fokus dalam kajian ini adalah pengaruh faktor struktur terhadap nilai tanah. Pengaruh faktor struktur tanah ini bergantung kepada penggunaan tanah. Klasifikasi penggunaan tanah telah dikemukakan oleh ramai penyelidik antaranya Ratcliff (1972), Anderson et al., (1976), Barlowe (1978) dan lain-lain. Barlowe (1978) membahagikan penggunaan tanah kepada 10 jenis, iaitu tempat kediaman, komersial dan industri, pertanian, padang rumput, hutan, perlombongan, rekreasi, perhubungan, perkhidmatan dan tanah tandus dan kering.

Faktor struktur adalah berhubungan dengan situasi fizikal lot tanah. Hal ini bermakna bahawa setiap kawasan dengan ciri-ciri atau sifat yang berbeza mempunyai faktor struktur yang berbeza pula. Kawasan pergunungan mempunyai sifat kecerunan yang curam dan ketinggian yang bervariasi. Ini menyebabkan kecerunan dan kontur mempengaruhi nilai tanah tersebut. Kawasan kajian di daerah Gubeng, Surabaya adalah bandar yang datar dengan majoriti penggunaan tanah adalah kediaman, 
komersial dan industri. Oleh itu, pemboleh ubah yang diambil kira untuk faktor struktur adalah arah, bentuk, luas dan lebar hadapan. Bentuk umum model yang dicadangkan adalah seperti berikut:

$$
H T=f(A R, L I, L S, L H)
$$

di mana

$$
\begin{aligned}
& H T=\text { Harga Transaksi Lot Tanah } \\
& A R=\text { Arah Lot Tanah } \\
& L I=\text { Indeks Landskap (bentuk) } \\
& L S=\text { Luas Lot Tanah } \\
& L H=\text { Lebar Hadapan }
\end{aligned}
$$

Nilai tanah dinyatakan dalam harga transaksi tanah. Arah diambil kira kerana kawasan kajian merupakan kawasan yang beriklim tropikal sehingga sinar matahari pada masa tertentu (pagi hari) menjadi pertimbangan. Bentuk diambil kira kerana dalam membina bangunan, ada bentuk-bentuk tertentu yang memudahkan perancangan bangunan sama ada perumahan mahupun komersial dan sebaliknya. Luas diambil kira kerana keluasan merupakan faktor struktur yang menunjukkan tingkat keupayaan di atas tanah (Nelson, 1993). Sesuatu pembangunan selalunya memerlukan keluasan lot tanah yang tertentu bagi memenuhi keperluan perancangan dan keuntungan minimum. Lebar hadapan diambil kira kerana di kawasan bandar sebuah lot tanah dengan lebar hadapan yang memadai mempunyai potensi untuk digunakan sebagai tempat kegiatan ekonomi (Brondino dan Silva, 1998).

\subsection{METODOLOGI KAJIAN}

\subsection{Pembangunan Pangkalan Data Ruangan}

Kawasan kajian adalah Bandar Surabaya dan kawasan sekitarnya yang terletak dalam daerah Gubeng yang terdiri daripada enam mukim (Rajah 1). Untuk membentuk model nilai tanah berdasarkan faktor struktur, dua lapisan peta diperlukan, iaitu peta lot dan peta lokasi transaksi lot. Peta lot tanah daerah Gubeng, Surabaya ditunjukkan dalam Rajah 1 dan peta lokasi transaksi lot dalam Rajah 2.

Dua lapisan lain yang ditunjukkan dalam Rajah 1 adalah sempadan daerah kajian dan sempadan bandar Surabaya. Jumlah lot yang terkandung dalam setiap mukim di daerah Gubeng ditunjukkan dalam Jadual 2.

Data lot tanah berasal daripada Direktoral Jendral Cukai di Indonesia yang menggunakan perisian MapInfo. Perisian yang digunakan untuk analisis adalah ArcView kerana mempunyai kemampuan dalam analisis ruangan. Peta lokasi transaksi lot tanah sebagaimana dalam Rajah 2, telah ditukar format ke dalam ArcView shape file (.shp) dengan menggunakan Universal Translator daripada Map Info tab file (*.tab). Senarai jumlah data transaksi tanah ditunjukkan dalam Jadual 3. 


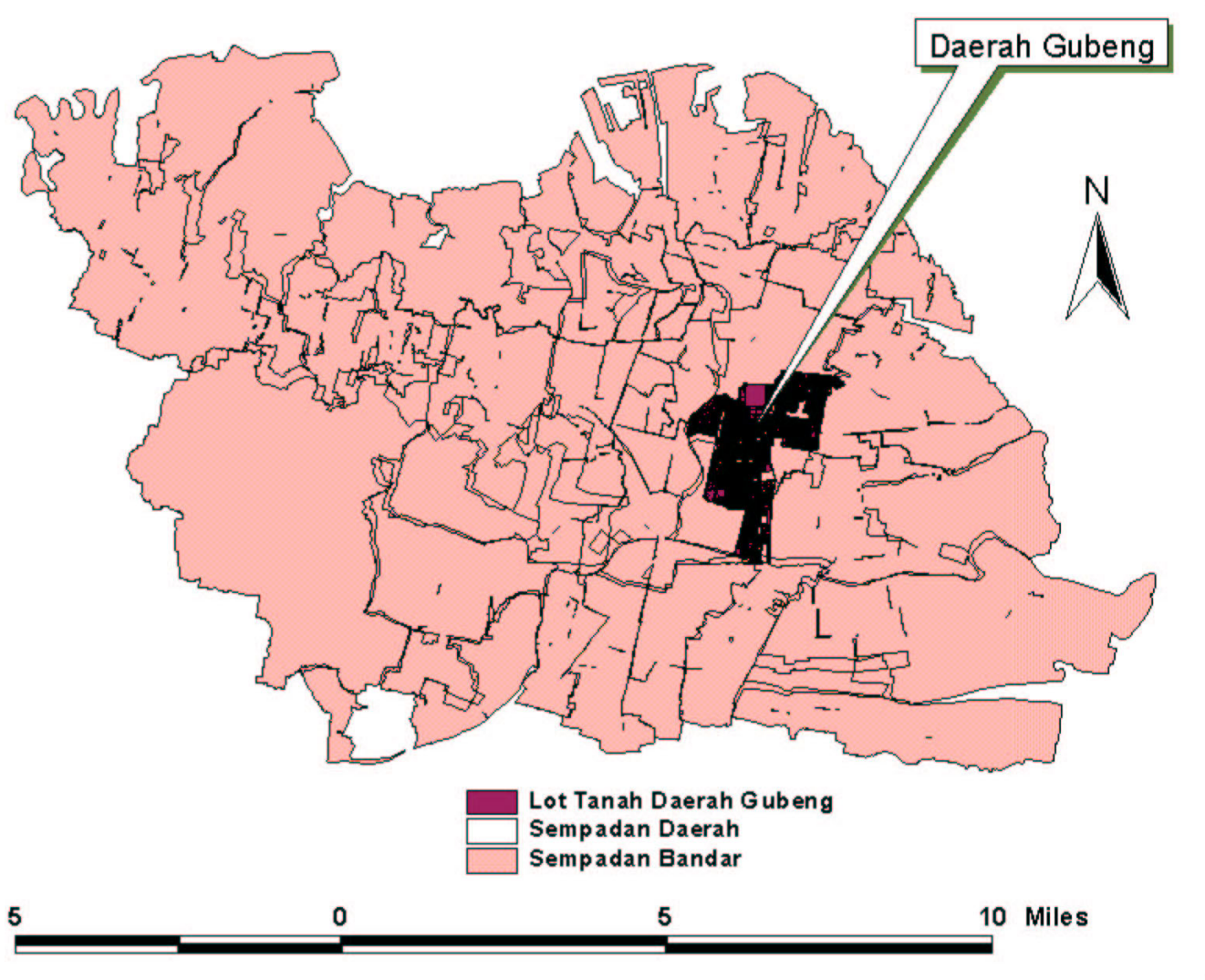

Rajah 1 Peta bandar Surabaya dan lot tanah kawasan kajian

Jadual 2 Jumlah lot untuk setiap mukim di daerah Gubeng

\begin{tabular}{|c|l|c|}
\hline No. & Mukim & Jumlah lot \\
\hline 1 & Baratajaya & 4,218 \\
\hline 2 & Pucangsewu & 3,092 \\
\hline 3 & Kertajaya & 4,361 \\
\hline 4 & Gubeng & 2,716 \\
\hline 5 & Airlangga & 3,963 \\
\hline 6 & Mojo & $\mathbf{8 , 2 6 7}$ \\
\hline & Jumlah keseluruhan & $\mathbf{2 5 , 7 5 3}$ \\
\hline
\end{tabular}




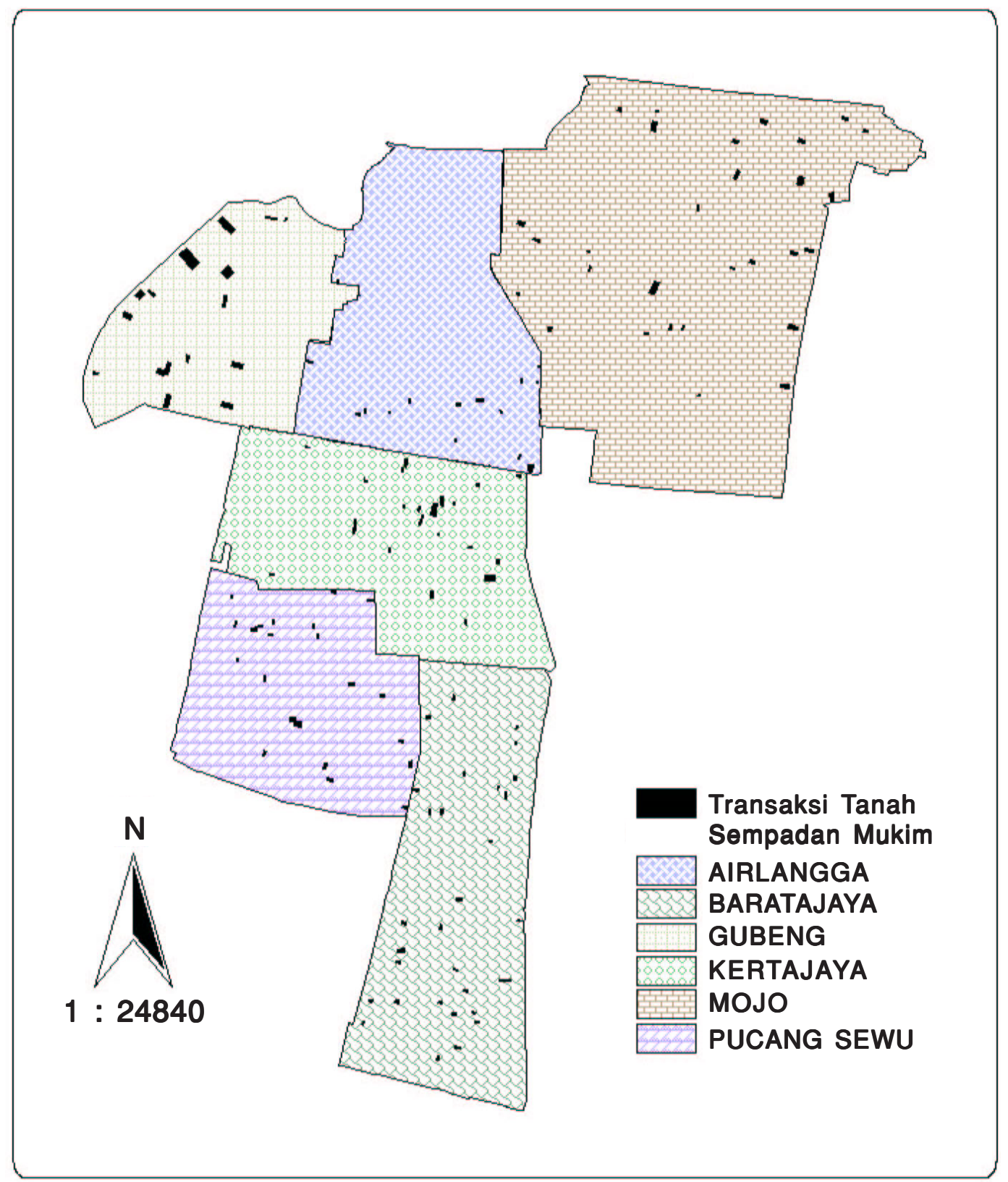

Rajah 2 Peta lokasi transaksi lot tanah

\subsection{Prosedur Analisis}

Analisis data yang digunakan untuk membentuk model nilai tanah terdiri daripada analisis ruangan dan analisis statistik. Rajah 3 menunjukkan carta aliran bagi analisis berkenaan. 
Jadual 3 Jumlah data transaksi lot di kawasan kajian

\begin{tabular}{|c|l|c|}
\hline No. & Nama Mukim & Jumlah Transaksi Lot \\
\hline 1 & Baratajaya & 35 \\
\hline 2 & Pucangsewu & 22 \\
\hline 3 & Kertajaya & 23 \\
\hline 4 & Gubeng & 18 \\
\hline 5 & Airlangga & 16 \\
\hline 6 & Mojo & 34 \\
\hline
\end{tabular}

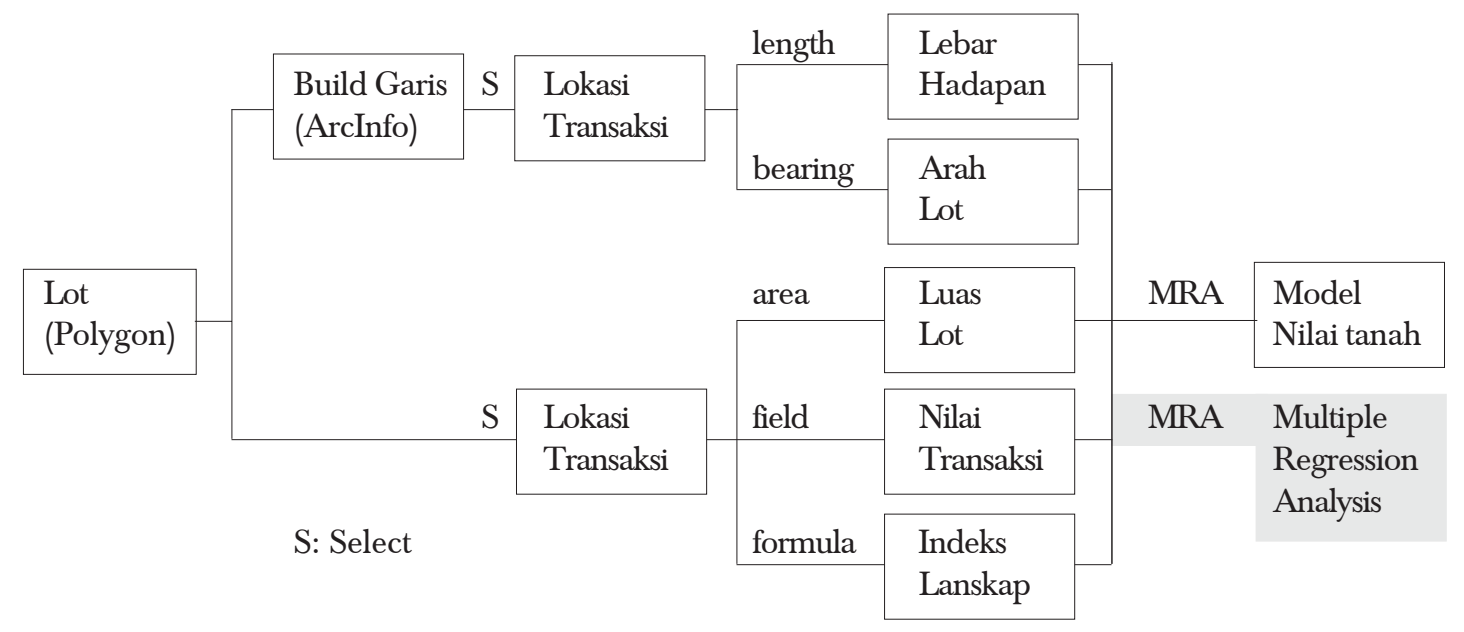

Rajah 3 Integrasi analisis ruangan dan statistik dalam membentuk model

Penggunaan analisis ruangan dan statistik dalam membentuk model nilai tanah dibincangkan secara terperinci pada bahagian berikut.

\subsubsection{Analisis Ruangan}

Dengan menggunakan keupayaan sistem maklumat geografi, beberapa analisis ruangan dijalankan bagi menjana data yang diperlukan oleh model yang dibentuk. Ini termasuklah analisis bagi mengira lebar hadapan lot, arah lot, keluasan, dan indeks landskap.

\section{(1) Lebar Hadapan}

Rangkaian proses dalam menghasilkan lebar hadapan dimulai dengan menggunakan perisian ArcInfo. Operasi Shapearc dilakukan untuk mengubah format 
shapefile dari ArcView ke file coverage dalam format Arc/Info. Selanjutnya operasi Clean dan Build garisan dilakukan untuk mengubah poligon ke bentuk garisan. Kemudian dengan perisian ArcView, file coverage lot kawasan kajian berjenis garisan diaktifkan. Dengan menggunakan operasi Convert to shapefile, coverage yang telah dihasilkan dalam Arc/Info diubah kembali menjadi shapefile ${ }^{1}$. Langkah berikutnya adalah memilih garisan bersebelahan dengan jalan. Dalam kes ini, poligon jalan telah dikodkan sebagai 1. Dalam ArcInfo maklumat perdampingan poligon kiri dan kanan diwakilkan secara automatik masingmasing dengan item Lpoly dan Rpoly. Oleh itu garisan yang mempunyai Lpoly atau Rpoly $=1$ dipilih sebagai garisan yang bersebelahan dengan jalan (Rajah 4). Panjang lebar hadapan boleh didapati pada item Length pada atribut theme garisan yang dipilih.

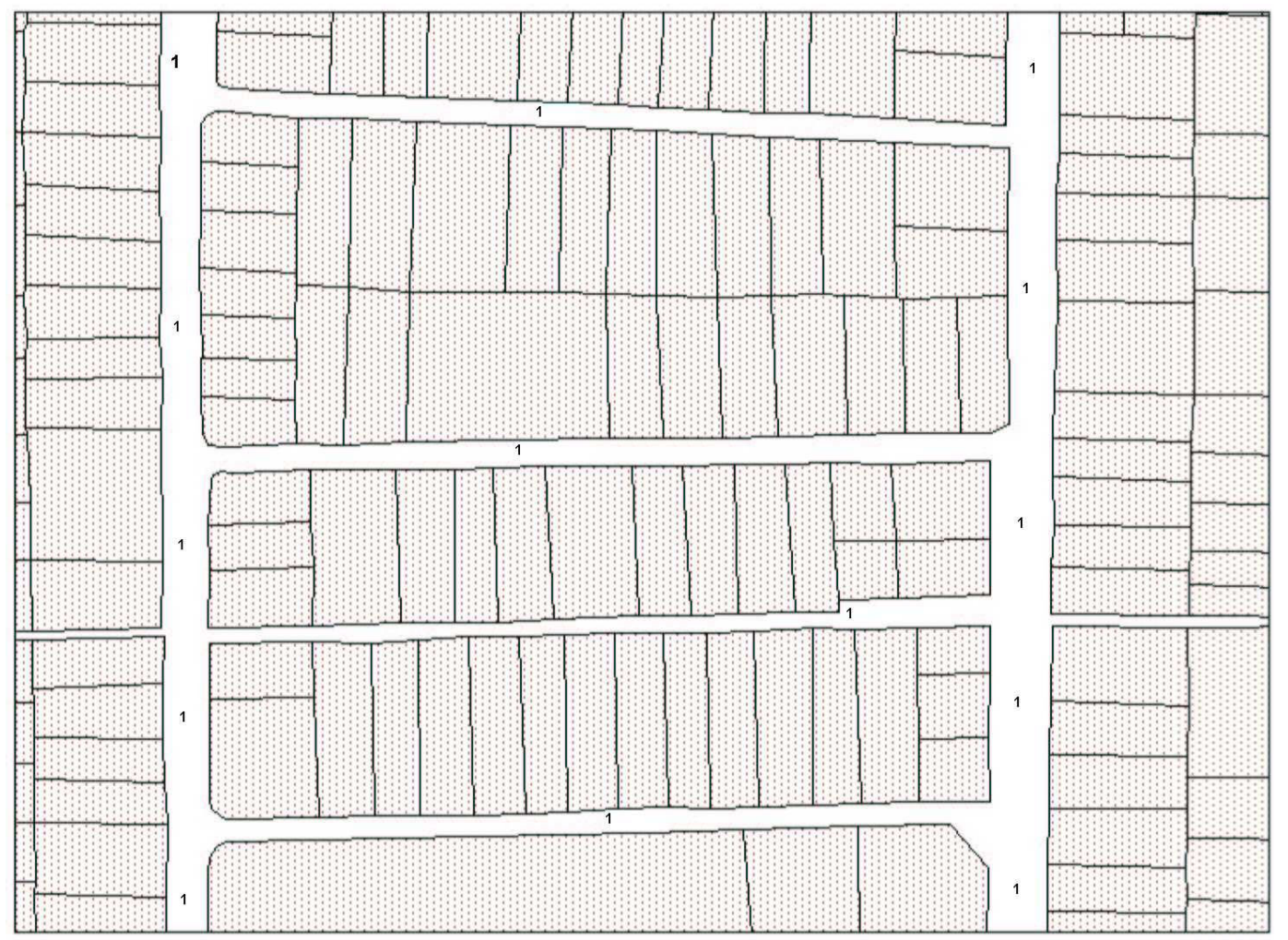

Rajah 4 Garisan dengan Lpoly=1 atau Rpoly=1 (lebar hadapan)

$1 \quad$ Walaupun perisian ArcView boleh membaca terus fail dalam format Arc/Info, namun pertukaran format diperlukan memandangkan ada beberapa fungsi dalam ArcView yang memerlukan (atau lebih efisien diproses) sesuatu fail dalam format ArcView sendiri, di samping fail dalam format ini lebih cepat diproses. 
(2) Arah Orientasi Lot

Rangkaian proses dalam menghasilkan arah lot diawali dengan mengedit lebar hadapan untuk lot hujung (corner lot). Proses pengeditan ini adalah proses pemotongan garisan lebar hadapan yang menghadap jalan yang lebih kecil, maknanya garisan yang menghadap jalan yang lebih lebar dipilih sebagai acuan dalam menentukan arah orientasi garisan (bearing) tersebut. Selanjutnya peta garisan lebar hadapan diproses dengan script untuk mendapatkan arah. Arah orientasi garisan yang dihasilkan dalam bentuk darjah adalah sebagaimana yang ditunjukkan dalam Rajah 5.

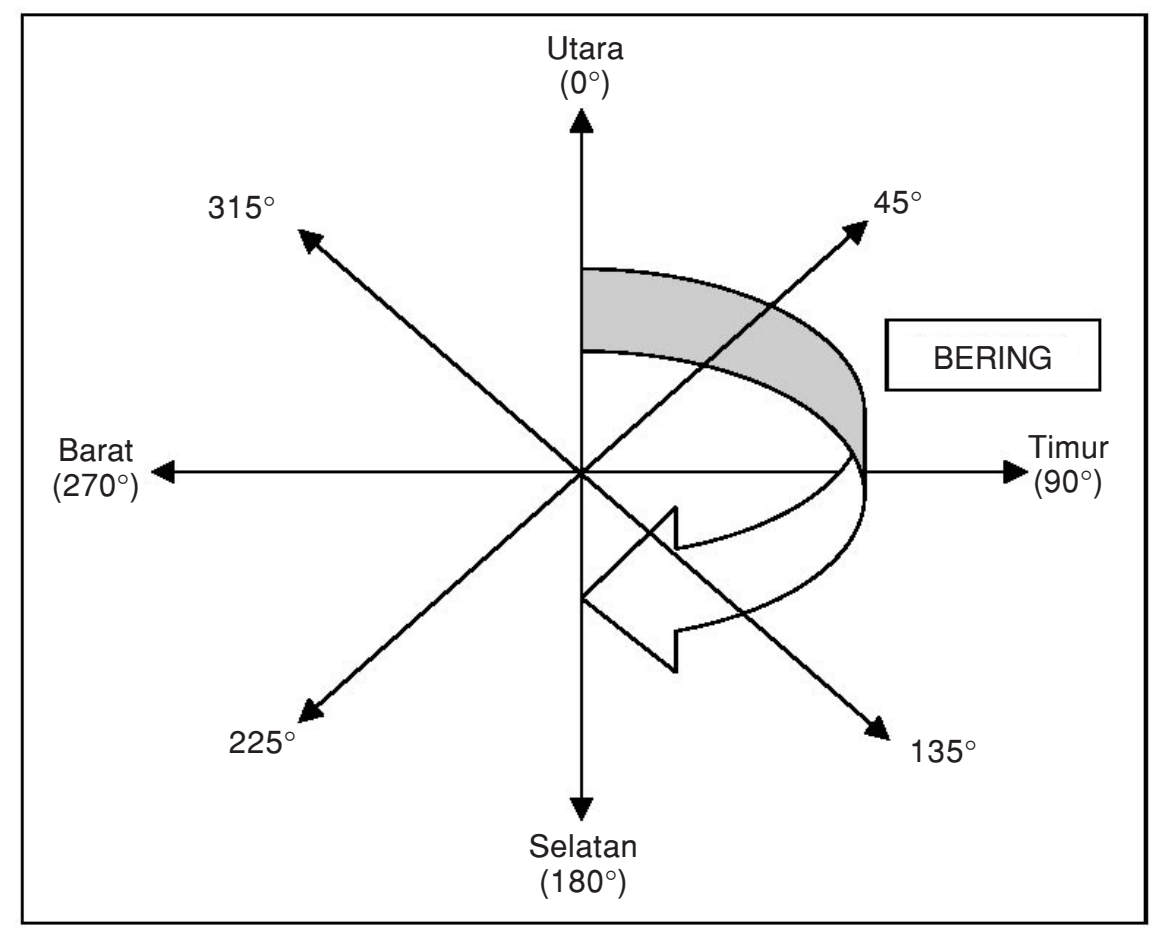

Rajah 5 Bering garis lebar hadapan

Arah orientasi garisan ditukarkan ke arah matahari terbit seperti yang ditunjukkan dalam Jadual 4.

(3) Luas Lot

Rangkaian proses dalam menghasilkan luas lot dimulai dengan mengaktifkan peta transaksi tanah dan memilih satu unit ukuran dalam View properties. Proses berikutnya adalah mengaktifkan extension Xtools dan memilih menu Update area, perimeter, acres and length. Hasil daripada luas poligon didapati pada item Area pada atribut theme tersebut. 
PERANAN FAKTOR STRUKTUR DALAM MODEL NILAI TANAH

Jadual 4 Pertukaran orientasi ke arah mata angin

\begin{tabular}{|c|l|l|c|}
\hline No. & Arah Mataangin & $\begin{array}{l}\text { Bering } \\
\text { (arah matahari terbit) }\end{array}$ & Nilai Dummy \\
\hline 1 & Timur & $46^{\circ}-135^{\circ}$ & 1 \\
\hline 2 & Selatan & $136^{\circ}-215^{\circ}$ & 0 \\
\hline 3 & Barat & $216^{\circ}-315^{\circ}$ & 0 \\
\hline 4 & Utara & $316^{\circ}-360^{\circ} \& 1^{\circ}-45^{\circ}$ & 0 \\
\hline
\end{tabular}

(4) Indeks Landskap

Indeks landskap yang digunakan ialah bentuk yang merupakan tingkat kepadatan lot. Indeks landskap ini merupakan nisbah jumlah panjang garisan sempadan (perimeter) poligon terhadap luas poligon (Haines \& Chopping, 1996). Dalam kes lot tanah, apabila luas lot sama, lebar hadapan juga sama. Walau bagaimanapun, ada satu kemungkinan yang berbeza iaitu bentuk lot seperti ditunjukkan dalam Rajah 6 .

Daripada Rajah 6 didapati bahawa semakin tinggi nilai indeks landskap, maka bentuk lot tanah semakin kurang padat atau kurang nilai bentuknya. Penerapan dalam perhitungan peta lot adalah nisbah daripada panjang garisan sempadan terhadap luas poligon.

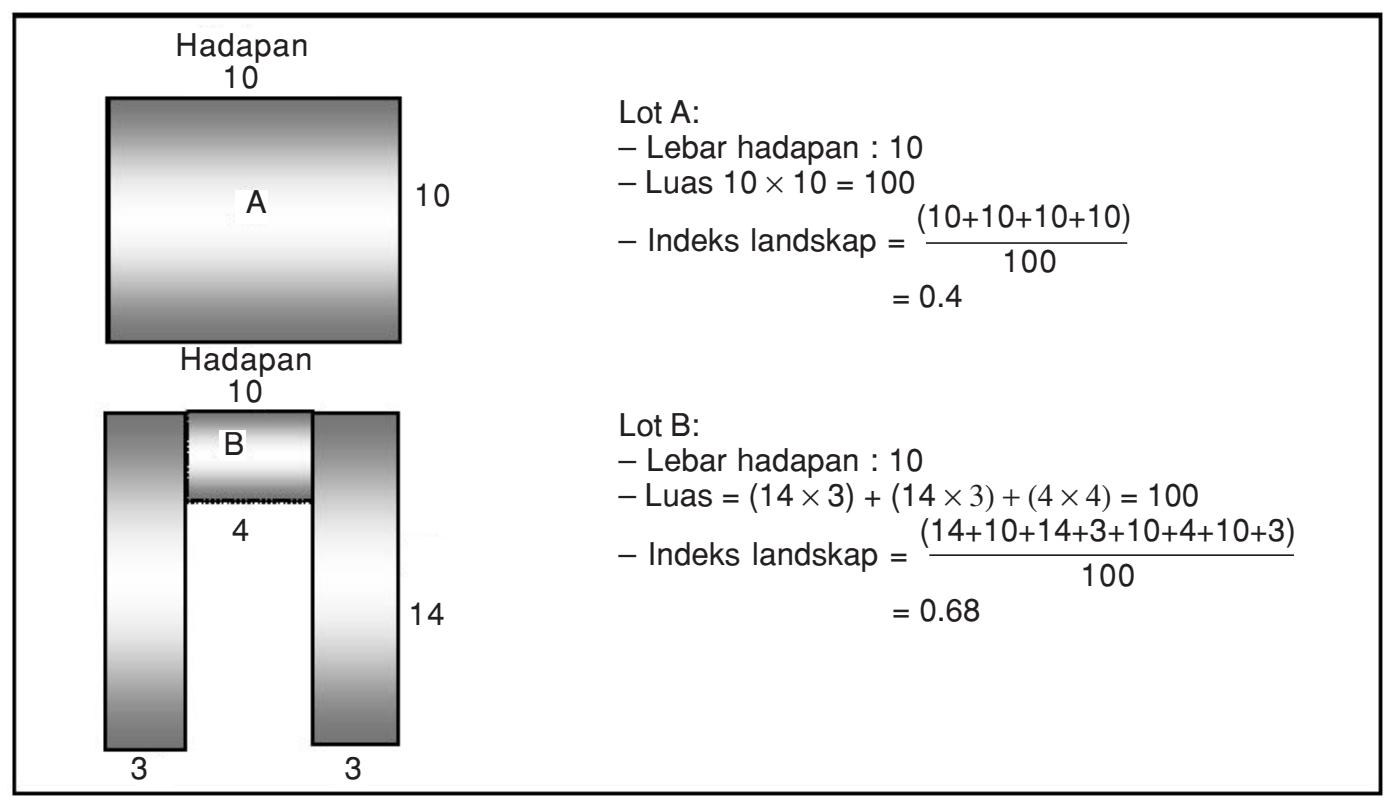

Rajah 6 Konsep indeks lanskap 
Nilai tanah untuk lokasi transaksi bagi kawasan kajian didapati daripada institusi kerajaan, nilai transaksi dalam rupiah ditukarkan dalam ringgit Malaysia (RM). Selanjutnya lapangan Nilai ditambahkan dan memasukkan data tersebut pada atribut theme.

\subsubsection{Analisis Statistik}

Selanjutnya data yang dihasilkan dari analisis ruangan diolah berdasarkan analisis statistik dengan kaedah regresi untuk membentuk model nilai tanah. Analisis ini digunakan kerana pemboleh ubah bersandar iaitu nilai tanah sebenar berbentuk data metrik (kuantitatif), sedangkan pemboleh ubah tak bersandar ada yang berbentuk data metrik dan ada yang berbentuk data non-metrik (Hair et al., 1995). Tujuan penggunaan kaedah regresi adalah untuk meramal perubahan dalam pemboleh ubah bersandar sebagai reaksi terhadap perubahan beberapa pemboleh ubah bebas (tak bersandar). Secara amnya, fungsi regresi boleh diberikan oleh persamaan di bawah:

$$
Y=a_{0}+a_{1} X_{1}+a_{2} X_{2}+a_{3} X_{3}+\ldots+a_{\mathrm{n}} X_{\mathrm{n}}+e
$$

metrik metrik \& non metrik

dengan

$Y \quad=$ Pemboleh ubah bersandar

$a_{0} \quad=$ Pemalar

$a_{1} \ldots a_{\mathrm{n}}=$ Pekali

$X_{1} \ldots X_{\mathrm{n}}=$ Pemboleh ubah bebas (tak bersandar)

$n \quad=$ jumlah faktor yang diambil kira

$e \quad=$ gangguan stokastik

Analisis statistik dijalankan terhadap semua 148 lot transaksi menggunakan perisian SPSS for Windows versi 10.

\subsection{HASIL}

Hasil pengolahan daripada perisian SPSS terhadap 148 transaksi tanah telah memberikan hasilan seperti yang ditunjukkan dalam Jadual 5 .

Hasilan ini menunjukkan hanya luas dan bentuk (indeks landskap) merupakan pemboleh ubah yang mempunyai pengaruh signifikan kepada nilai tanah pada tahap $\alpha=0.05$. Sedangkan lebar hadapan dan arah orientasi adalah pemboleh ubah yang tidak signifikan. Ini menunjukkan lebar hadapan dan arah orientasi lot tidak memainkan peranan penting dalam menentukan nilai tanah di kawasan kajian. Oleh yang demikian, model nilai tanah yang terbentuk adalah seperti berikut: 
Jadual 5 Hasil analisis regresi

\begin{tabular}{|l|c|c|}
\hline Pemboleh ubah & Pekali & $\begin{array}{c}\text { Tahap } \\
\text { kesignifikanan }\end{array}$ \\
\hline Pemalar & $-224,608$ & 0.000 \\
\hline Luas lot $(\mathrm{X} 1)$ & $1,022.0$ & 0.000 \\
\hline Lebar hadapan (X2) & $-4,306.0$ & 0.113 \\
\hline Indeks landskap/bentuk (X3) & $326,765.7$ & 0.004 \\
\hline Arah Matahari (X4) & $-4,152.2$ & 0.866 \\
\hline & & \\
\hline Adjusted $R$ square & 0.743 & 0.000 \\
\hline
\end{tabular}

$$
\mathrm{Y}=-224608+1022.0 \mathrm{X}_{1}+326765.7 \mathrm{X}_{3}
$$

Hasil perhitungan Adjusted R Square adalah 0.743, bermakna pemboleh ubah bebas mempengaruhi pemboleh ubah bersandar sebesar $74 \%$. Hasil perhitungan uji $\mathrm{F}$ adalah 107.444 dengan tahap signifikan $\alpha=0.000$, menunjukkan bahawa secara keseluruhan model adalah signifikan dan pemilihan pemboleh ubah adalah tepat. Bagaimanapun, masih terdapat kira-kira 26\% daripada variasi nilai tanah yang tidak dapat diterangkan oleh model yang terbentuk. Ini menunjukkan ada pemboleh ubah lain yang mempengaruhi nilai tanah seperti faktor-faktor kejiranan dan lokasi.

\subsection{PERBINCANGAN DAN RUMUSAN}

Kajian ini telah membentuk satu model bagi nilai tanah dengan memberi fokus kepada faktor struktur dengan bantuan sistem maklumat geografi (GIS). Empat pemboleh ubah struktur telah dinilai iaitu luas, lebar hadapan, bentuk (indeks landskap) dan arah orientasi lot. Data bagi pemboleh ubah-pemboleh ubah ini sukar dijana tanpa bantuan GIS terutamanya bagi kawasan yang luas. Model yang dihasilkan menunjukkan bahawa hanya luas dan bentuk lot sahaja yang signifikan dalam mempengaruhi nilai tanah. Luas masih merupakan pemboleh ubah dengan tingkat keupayaan tertinggi dalam mempengaruhi nilai tanah. Sedangkan bentuk lot yang merupakan pemboleh ubah indeks landskap adalah pemboleh ubah kedua signifikan. Hasil ini menunjukkan bahawa bentuk lot tanah mempengaruhi kemudahan reka bentuk binaan sehingga mempengaruhi nilai tanah. Lebar hadapan adalah tidak signifikan namun pada tingkat yang lebih baik daripada arah lot. Ini bermakna bahawa lebar hadapan merupakan satu faktor yang dipertimbangkan kerana lot dengan lebar hadapan yang memadai lebih mudah digunakan untuk binaan persendirian mahupun komersial. Pemboleh ubah dummy arah orientasi lot (arah matahari terbit) adalah tidak signifikan kerana dengan kemajuan senibina berbagai kaedah boleh digunakan 
untuk mendapatkan sinar matahari pagi secara lebih baik tanpa harus memperhatikan arah lot tanah.

Secara keseluruhan model menyumbangkan 74\% daripada seluruh faktor yang mempengaruhi nilai tanah. Ini menunjukkan faktor struktur memainkan peranan penting dalam menentukan nilai tanah. Namun begitu, sebesar 26\% nilai tanah masih dipengaruhi faktor-faktor yang lain. Daripada 25,753 lot tanah di kawasan kajian maka jumlah sampel $148(0.58 \%)$ nilai tanah adalah terlalu kecil dalam menghasilkan model untuk peramalan. Data sampel nilai transaksi ini dikumpulkan daripada pejabat cukai hartanah tahun 1998 dan 1999, sedangkan dari ejen hartanah data transaksi masih dianggap sebagai data sulit, sehingga tak dapat diperolehi. Untuk dapat menghasilkan model nilai tanah yang boleh digunakan untuk peramalan maka diperlukan jumlah sampel yang lebih besar untuk membentuk dan menguji model, dengan ditambahkan faktor-faktor lain seperti kejiranan, lokasi dan masa sehingga secara keseluruhan meningkatkan sumbangan seluruh faktor terhadap nilai tanah. Dengan perkembangan penggunaan sistem maklumat geografi di agensi-agensi tanah dan percukaian di Indonesia sejak kebelakangan ini diharapkan data-data yang lengkap lebih mudah diperolehi bagi menjalankan penyelidikan yang lebih menyeluruh di masa depan.

\section{PENGHARGAAN}

Penulis ingin mengucapkan terima kasih kepada 2 penilai bebas yang telah memberi ulasan serta komen berguna dalam memperbaiki kualiti penulisan ini. Penulis juga ingin berterima kasih kepada Direktorat Jendral Pajak Departemen Keuangan Republik Indonesia dan Kantor Pelayanan Pajak Bumi dan Bangunan wilayah Surabaya yang telah menyediakan data yang diperlukan bagi menjayakan kajian ini.

\section{RUJUKAN}

Anderson, et. al. 1976. A Land Use and Land Cover Classification System for Use with Remote Sensor Data. U.S. Geological Survey. Professional Paper 964, Reston, VA.

Barlowe, R. 1978. Land Resource Economics. USA: Prentice Hall, Inc.

Brondino, N. C. M. dan A. N. R. Silva. 1998. Combining Artificial Neural Networks and GIS for Land Valuation Purposes. India: Proceedings of the Computers in Urban Planning and Urban Management.

Castle, G. H. 1992. Profit of GIS Real Estate. California: Wesley Publishing Co.

Dirjen Cukai. 1998. Sistem Pengurusan Maklumat Objek Cukai (SISMIOP). Jakarta: Direktorat Cukai Bumi dan Bangunan.

Dowall, D. E. dan M. Leaf. 1991. The Price of Land for Housing in Jakarta. Urban Studies 28: 707-722.

Dubin, R. 1998. Predicting House Prices Using Multiple Listings Data. Journal of Real Estate Finance and Economics. 17(1): 35-59.

Farber, S. 1986. Market Segmentation and the Effects on Group Homes for the Handicapped on Residential Property Values. Urban Studies 23: 519-525.

Haines, R. dan M. Chopping. 1996. Quantifying Landscape Structure: A review of Landscape Indices and Their Application to Forested Landscapes. Progress in Physical Geography 20: 418-445.

Hair, Joseph F. Jr., R. E. Anderson, R. L. Tatham dan W. C. Black. 1995. Multivariate Data Analysis with Readings. USA: Prentice-Hall, Inc. 
Nelson, A. C. 1993. Disamenity Influences of Edge Cities on Exurban Land Values: A Theory with Empirical Evidence and Policy Implications. Urban Studies 30: 1683-1690.

Ratcliff, R. U. 1972. Urban Land Economics. USA: McGraw-Hill.

Ruslan, R. dan M. S. Noresah. 1998. Sistem Maklumat Geografi. Kuala Lumpur: Dewan Bahasa dan Pustaka.

Sun Sheng Han dan Ann Basuki. 2001. The Spatial Pattern of Land Values in Jakarta. Urban Studies, 38(10): 18411857.

Wyatt, P. 1996. Practice Paper: Using a Geographical Information System for Property Valuation. Property Valuation and Investment 1: 14-20. 